\title{
Antibacterial Activity and Active Fraction of Zingiber officinale Roscoe, Zingiber montanum (J.Koenig) Link ex A., and Zingiber zerumbet (L.) Roscoe ex Sm. Against Propionibacterium acnes
}

\author{
N Aji ${ }^{1,2}$, S Kumala ${ }^{1 *}$, E Mumpuni' ${ }^{1}$, D Rahmat ${ }^{1}$
}

N Aji ${ }^{1,2 *}$, S Kumala'* ${ }^{1 *}$ E Mumpuni', D Rahmat ${ }^{1}$

${ }^{1}$ Faculty of Pharmacy, Pancasila University, Jakarta, INDONESIA.

${ }^{2}$ Department of Pharmacy, Poltekkes Kemenkes Tasikmalaya, Tasikmalaya, INDONESIA.

\section{Correspondence}

\section{S Kumala}

Faculty of Pharmacy, Pancasila University, Jakarta, Department of Pharmacy Indonesia.

E-mail: fskumala@univpancasila.ac.id History

- Submission Date: 18-11-2021;

- Review completed: 11-12-2021;

- Accepted Date: 13-12-2021.

DOI : 10.5530/pj.2022.14.15

Article Available online

http://www.phcogj.com/v14/i1

\section{Copyright}

(C) 2022 Phcogi.Com. This is an openaccess article distributed under the terms of the Creative Commons Attribution 4.0 International license.

\begin{abstract}
Background: Propionibacterium acnes is a commensal bacteria that play a role in developing acne vulgaris on the skin. Antibacterial activity assay in the last decades have shown that Propionibacterium acnes is resistant to several antibiotics. Potential zingiber genera such as $Z$. officinale, $Z$. montanum, and $Z$. zerumbet have potential as antibacterial. Objective: This study aims to compare the antibacterial activity of $Z$. officinale, $Z$. montanum and $Z$. zerumbet against Propionibacterium acnes, the active fraction, and the components of the active fraction of the plant. Materials and Methods: Antibacterial activity test using agar diffusion method, extracts with high antibacterial activity were partitioned with water: n-hexane, n-hexane: methanol, water: ethyl acetate. The fraction was tested for antibacterial activity against $P$. acnes. The active fraction obtained was identified for its phytochemical content using TLC and GC-MS methods. Results: The results of the antibacterial activity test of $Z$. officinale extract had a larger inhibition zone. The test results of the active fraction $Z$. officinale had a higher activity than the extract. The results of screening using the GC-MS method obtained that the main components identified from $Z$. officinale were volatile oil components ( $\alpha$-curcumene, $\alpha$-zingiberene and zingerone) and oleoresin (6-shogaol). Conclusion: Extracts of Z. officinale, Z. montanum and Z. zerumbet had antibacterial activity against $P$. acnes. The highest antibacterial activity in $Z$. officinale both extract and ethyl acetate fraction which is known to contain terpenoids and oleoresin compounds (6-shogaol).
\end{abstract}

Key words: Antibacterial, Zingiber officinale, Zingiber montanum, Zingiber zerumbeth, Propionibacterium acnes.

\section{INTRODUCTION}

Propionibacterium acnes is a commensal bacteria found in the sebaceous glands. ${ }^{1}$ Apart from being a normal flora on the skin, these bacteria can act as opportunistic pathogenic bacteria in acne vulgaris. Colonization of pilosebaceous follicles by $P$. acnes is one of the main factors that cause acne by taking part in the skin inflammatory response ${ }^{2}$. In addition to manipulating the host immune response, $P$. acnes can form biofilms and make associations with other bacteria ${ }^{3}$. Resistance of $P$. acnes to antibiotic therapy has gradually emerged over the years as a global problem, with high rates of resistance reported for erythromycin (macrolide) and clindamycin (lincosamide) between 21\%-70\%, for tetracyclines between $4 \%-70$. 30\%. The most common mechanism of antibiotic resistance in $P$. acnes is chromosomal point mutations, particularly in the 23S rRNA gene for macrolide resistance and the $16 \mathrm{~S}$ rRNA gene for tetracycline resistance. ${ }^{2}$

The genus Zingiber has been widely used in the world of health as alternative medicine. Several groups of compounds in the Zingiber genus are known to have an antibacterial activity such as oleoresins, terpenoids, and flavonoids. ${ }^{4,5}$ Several plants of the genus Zingiber are widely distributed in Indonesia, three of which are: Zingiber officinale, Zingiber montanum and Zingiber zerumbet. The three species have advantages in terms of the main content they have. Zingiber officinale L. contains oleoresins such as gingerol and shogaol, ${ }^{6}$ Zingiber montanum contains the main content of Terpinen4-ol, sabinene, kassumunin and flavonoids. ${ }^{7,8}$ While Zingiber zerumbet has the main component in the form of sesquiterpene derivative compounds such as zerumbone and humuladien. ${ }^{9}$ Seeing the potential of the three plants, it is necessary to research the antibacterial potential of the three species of the genus Zingiber against Propionibacterium acnes and screening for active compounds.

\section{MATERIALS AND METHODS}

\section{Materials}

The plant material used was taken from Ciamis Regency, West Java Province, Indonesia. Crops were harvested on March 24, 2021 and then determined. Voucher specimens are stored at the Bandungense Herbarium, Bandung Institute of Technology, with registration numbers: Zingiber officinale Roscoe namely FIPIA-DEP30, Zingiber montanum (J.Koenig) Link ex A., namely FIPIA-DEP29 and Zingiber zerumbet (L.) Roscoe ex Sm. , namely FIPIADEP27. The bacteria used were Propionibacterium acne ATCC 11827, the culture medium was Nutrien Agar (Oxoid), and dimethyl sulfoxide /DMSO 99,9 $\%$ (Merck) as extract solvent. The materials used in the extraction process are ethanol $70 \%$, the materials used for fractionation are methanol, ethylacetate 99.8\% (Satyam), n-hexane $99.9 \%$ (Alfa), and aquadestylates (Brataco). Materials used for TLC: Silica Gel 60 F254 (Merck) was used in stationary phase with methanol (Merck) as mobile phase, and 
Chloroform (Fisher Scientific). The tools used for GC-MS analysis are: GC Aginelt series 7890A MS detector agilent 5977B GC/MSD brand, the column used is DB-5MS (5\%-phenyl)-methylpolysiloxane) column with a length of $30 \mathrm{~m}$ with a diameter of $0.25 \mathrm{~mm}$.

\section{Extraction and quality parameter of extract}

A total of 1000 grams of simplicia powder Z. officinale, Z. montanum. and $Z$. zerumbet were extracted using the maceration method with $70 \%$ ethanol solvent, the amount of solvent used was 1:10 (g: $\mathrm{mL})$ of the total simplicia. The duration of maceration is once 24 hours with two replacement solvents with the same amount and type of solvent. ${ }^{10}$ The extract was concentrated using a rotary evaporator at a temperature of $50^{\circ} \mathrm{C}$ with a pressure of $-0.8 \mathrm{BAR}$. The extract was then screened for phytochemicals including: alkaloids, polyphenols, tannins, flavonoids, saponins, troterpenoids and steroids. The phytochemical screening procedure was adopted from the Farnsworth method. ${ }^{11}$ The characteristic test of the extract included: water content, essential oil content, residual solvent content, total ash content, acid insoluble ash content, drying shrinkage, and total curcuminoid content for Zingiber montanum, the test procedure and extract quality parameters refer to the Indonesian Herbal Pharmacopoeia 2nd Edition, ${ }^{12}$ except that the measurement of the residual ethanol content refers to the Indonesian Pharmacopoeia 3rd Edition. ${ }^{13}$

\section{Total flavonoid assay}

A sample of $200 \mathrm{mg}$ was put into an erlenmeyer, added $25 \mathrm{~mL}$ of ethanol P, stirred for one hour with a magnetic stirrer. Filter into a 25 $\mathrm{mL}$ volumetric flask, rinse the filter paper with ethanol $\mathrm{P}$ and add up to the mark. Preparation of the comparison solution by weighing 10 $\mathrm{mg}$ of quercetin using a micro-analytical balance, put it into a $25 \mathrm{~mL}$ volumetric flask, dissolve and add ethanol P, until the mark. Make a series of dilutions of solutions of $100,75,60,50,25$, and $10 \mathrm{ppm}$. Pipette separately $0.5 \mathrm{~mL}$ of the test solution and each series of reference solutions into a suitable container, add each $1.5 \mathrm{~mL}$ of ethanol P, 0.1 $\mathrm{mL}$ of $10 \% \mathrm{AlCl}_{3} \mathrm{P}, 0.1 \mathrm{~mL}$ of $1 \mathrm{M}$ sodium acetate and 2.8 water. Shake and let sit for 30 minutes at room temperature. Measure the absorption at max. Create a calibration curve and calculate the percentage of flavonoids. ${ }^{12}$

\section{Fractionation}

Fractionation using liquid-liquid phase extraction. The solvent is selected based on the polarity index gradient taking into account the miscibility of the solvent phase. The solvents used are water: $n$-hexane (1:1), n-hexane: methanol (1:1), water: ethyl acetate (1:1). The flow of fractionation can be seen in Figure $1 .^{14}$

\section{Antibacterial assay}

Antibacterial activity was tested by disc diffusion method. The media used is Nutrient Agar. The extract solvent was DMSO 10\% and the number of samples tested was $20 \mu \mathrm{L}$ which was dripped into a blank disk $(\varnothing 6 \mathrm{~mm})$. Incubation at $37^{\circ} \mathrm{C}$ for 24 hours under anaerobic conditions. ${ }^{15}$ Extracts of $Z$. officinale, $Z$. montanum and Z. zerumbet were prepared in three concentrations of $5 \%, 10 \%, 15 \%$ and DMSO $10 \%$ as blanks. Extracts that have a high inhibition zone against $P$. acnes were continued with fractionation and identification of active compounds.

\section{Screening of active fraction phytochemical components using TLC and GC-MS}

The first step of screening active fraction components using the TLC method with the stationary phase is silica gel 60 F254. The mobile phase used was methanol and chloroform (5:95) for the identified curcumin and quercetin of active fraction. Component screening for volatile compounds using GC-MS with the following conditions: run time 49.5 minutes, heater $200{ }^{\circ} \mathrm{C}$, pressure 7.6522 psi, total flow $54 \mathrm{~mL} / \mathrm{min}$.

\section{Data analysis}

The data were analyzed using the ANOVA (Analysis of Variance) method to see the difference between the test groups with a $95 \%$ confidence level. Prior to the ANOVA test, homogeneity and normality tests were carried out on the data. The results of the ANOVA test were followed by LSD (Least Significant Difference) to see the differences between the groups.

\section{RESULTS}

The results of the extraction from each of 1000 grams of simplicia powder obtained 125.8 grams of $Z$. officinale extract (yield 12.58\%), 135 grams of $Z$. montanum extract (13.50\% yield) and 99.59 grams of $Z$. zerumbet extract (9.96\% yield) (Table 1$)$. The amount of yield of $Z$. montanum did not meet the requirements of the Indonesian Herbal Pharmacopoeia 2nd Edition.

The results of phytochemical screening showed that the extracts of $Z$. officinale, $Z$. montanum and $Z$. zerumbet contained alkaloids, polyphenols, flavonoids, and triterpenoids. The differentiator of the phytochemical content is that $Z$. montanum contains steroids and $Z$. zerumbet contains saponins (Table 2). The test results of extract parameters can be seen in Table 3. Determination of extract parameters is very important, several parameters can affect the test activity such as water content, ethanol residue, essential oil content, total ash content, acid-insoluble ash content and total curcuminoid content. Extract parameter requirements can be seen in Table 4 .

The results for total flavonoid levels are shown in Figure 2. The highest total flavonoid content was in the $Z$. montanum extract and the lowest was in the $Z$. officinale extract. Measurement of flavonoid levels using $\mathrm{UV}$-Vis spectrophotometer method with reagents $\mathrm{AlCl}_{3}(10 \%)$ and $1 \mathrm{M}$ Na-Acetate. ${ }^{12}$ Measurements were made at $\lambda 455 \mathrm{~nm}$, the wavelength is the maximum absorption for the reaction of flavonoids with $\mathrm{AlCl}_{3}$ (Figure 3).

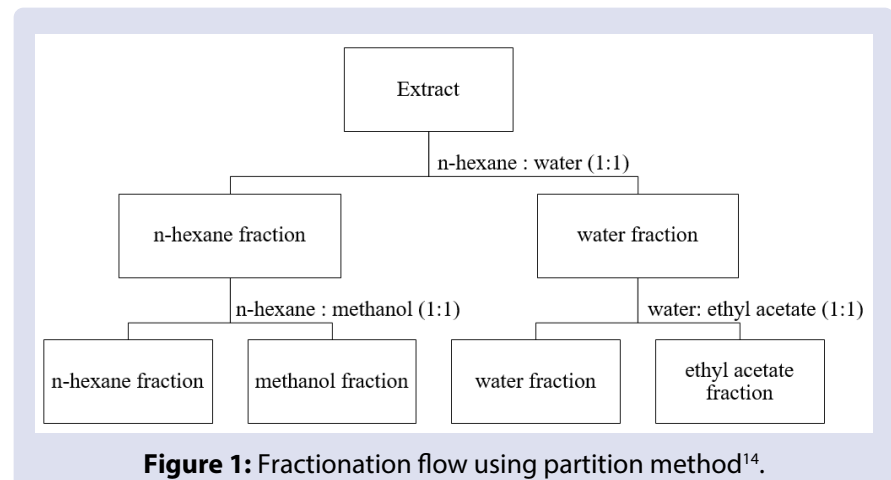

Figure 1: Fractionation flow using partition method ${ }^{14}$.

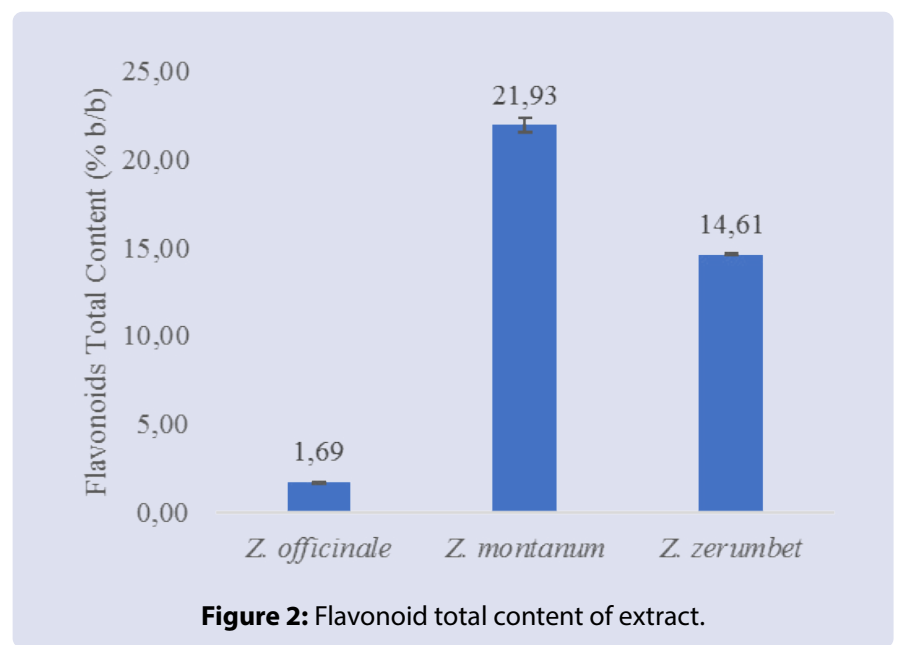




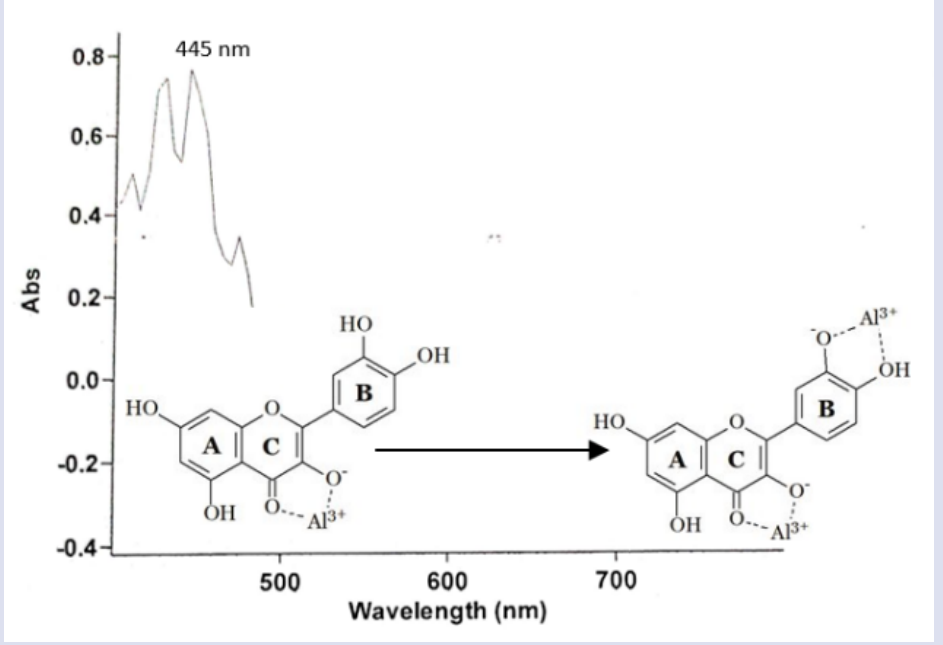

Figure 3: $\lambda_{\max }$ of the complex reaction of flavonoids and aluminium ion ${ }^{17}$.

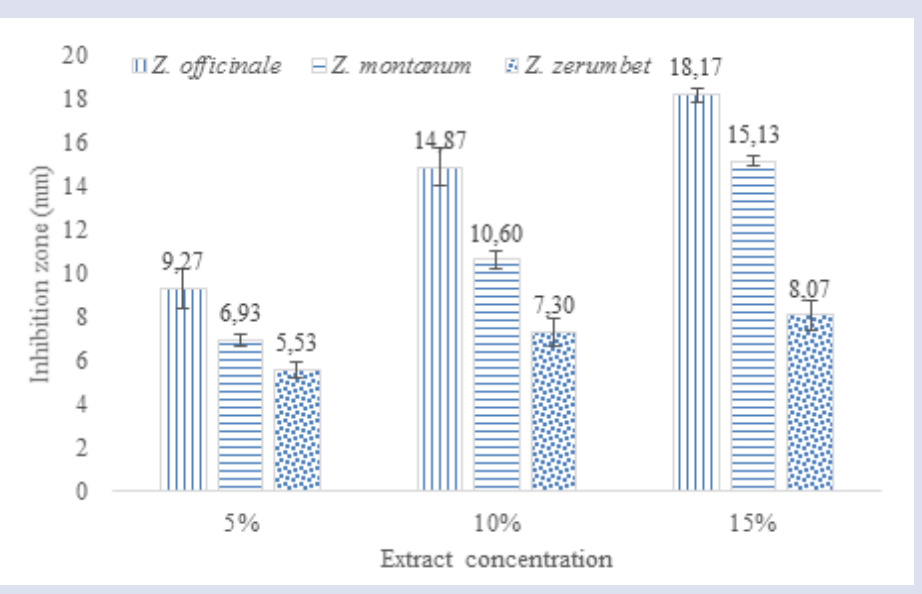

Figure 4: Antibacterial activity of $Z$. officinale, $Z$. montanum and Z. zerumbet extract.

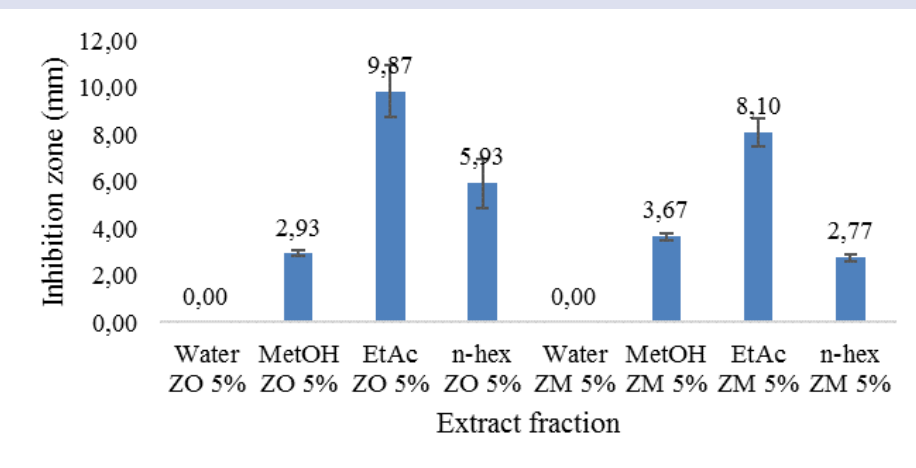

Figure 5: Antibacterial activity of Z. officinale(ZO), Z. montanum(ZM) fraction.

Table 1: The Result of extract through the maceration method.

\begin{tabular}{|ccccc|}
\hline Extract & $\begin{array}{c}\text { Simplicia Weight } \\
\text { (gram) }\end{array}$ & Extract weight (gram) & Yield (\%, b/b) & Requirements(12) (\%) \\
\hline Z. officinale & 1000 & 125.8 & 12.58 & 5.9 \\
Z. montanum & 1000 & 135 & 13.50 & 15 \\
Z. zerumbet & 1000 & 99.58 & 9.96 & 5.5 \\
\hline
\end{tabular}


Table 2: Phytochemical screening results.

\begin{tabular}{|c|c|c|c|c|}
\hline No & Compound Group & Z. officinale & Z. montanum & Z. zerumbet \\
\hline 1 & Alkaloids & + & + & + \\
\hline 2 & Polyphenol & + & + & + \\
\hline 3 & Tannin & - & - & - \\
\hline 4 & Flavonoids & + & + & + \\
\hline 5 & Saponins & - & - & + \\
\hline 6 & Steroids & - & + & - \\
\hline 7 & Triterpenoids & + & + & + \\
\hline
\end{tabular}

Note:

+ : positive towards compounds.

- : negative towards compounds.

\section{Table 3: Extract parameter test results.}

\begin{tabular}{llccc}
\hline No. & Kind of Assay & Z. officinale (\%) & $\begin{array}{c}\text { Z. montanum } \\
(\%)\end{array}$ & $\begin{array}{c}\text { Z. zerumbet } \\
\text { (\%) }\end{array}$ \\
\hline 1 & Total ash content (w/w) & $3.98 \pm 0.35$ & $3.57 \pm 0.19$ & $1.61 \pm 0.08$ \\
2 & Acid-insoluble ash content (w/w) & $1.16 \pm 0.01$ & $1.09 \pm 0.03$ & $0.57 \pm 0.01^{*}$ \\
3 & Essential oil content (v/w) & $1.60 \pm 0.69^{*}$ & $3.73 \pm 0.61$ & $1.33 \pm 0.61^{*}$ \\
4 & Residual ethanol solvent (w/w) & $0.44 \pm 0.04$ & $0.84 \pm 0.02$ & $0.06 \pm 0.05$ \\
5 & Water content (v/w) & $9.76 \pm 0.34$ & $9.11 \pm 0.59$ & $7.32 \pm 0.25$ \\
6 & Curcuminoid Total (w/w/) & - & $1.65 \pm 0.10^{*}$ & -
\end{tabular}

Note: ${ }^{*}=$ Does not fullfill the requirements.

Table 4: Extract parameter test requirements.

\begin{tabular}{|c|c|c|c|c|}
\hline No. & Kind of Assay & Z. officinale (\%) & $\begin{array}{l}\text { Z. montanum } \\
(\%)\end{array}$ & $\begin{array}{l}\text { Z. zerumbet } \\
(\%)\end{array}$ \\
\hline 1 & Total ash content $(\mathrm{w} / \mathrm{w})^{12}$ & $<5.00$ & $<7.60$ & $<0.70$ \\
\hline 2 & Acid insoluble ash content $(\mathrm{w} / \mathrm{w})^{12}$ & $<3.50$ & $<1.90$ & $<0.40$ \\
\hline 3 & Essential oil content $(\mathrm{v} / \mathrm{w})^{12}$ & $\geq 2.40$ & $\geq 1.20$ & $\geq 2.30$ \\
\hline 4 & Residual ethanol solvent (w/w) ${ }^{16}$ & $<5.00$ & $<5.00$ & $<5.00$ \\
\hline 5 & Water content $(\mathrm{v} / \mathrm{w})^{12}$ & $<10.00$ & $<10.00$ & $<10.00$ \\
\hline 6 & Curcuminoid Total (w/w/) ${ }^{12}$ & - & $\geq 1.65$ & - \\
\hline
\end{tabular}

Table 5: Phytochemical components identified in the Z. officinale ethyl acetate fraction by GC-MS.

\begin{tabular}{|c|c|c|c|c|c|}
\hline No. & Name of the Compound & Retention Time & $\begin{array}{l}\text { Molecular weight } \\
(\mathrm{g} / \mathrm{mol})\end{array}$ & $\begin{array}{l}\text { Peak Area } \\
\text { (\%) }\end{array}$ & Formula \\
\hline 1 & Decanal & 15.40 & 156.27 & 2.17 & $\mathrm{C}_{10} \mathrm{H}_{20} \mathrm{O}$ \\
\hline 2 & Trifluoroacetyl-lavandulol & 20.06 & 250.26 & 0.79 & $\mathrm{C}_{12} \mathrm{H}_{17} \mathrm{~F}_{3}$ \\
\hline 3 & a-Curcumene & 22.73 & 202.34 & 1.8 & $\mathrm{C}_{15} \mathrm{H}_{22}$ \\
\hline 4 & a-Zingiberene & 23.07 & 204.35 & 2.76 & $\mathrm{C}_{15} \mathrm{H}_{24}$ \\
\hline 5 & trans- $\beta$-Farnesene & 23.78 & 204.35 & 1.21 & $\mathrm{C}_{15} \mathrm{H}_{24}$ \\
\hline 6 & Frambinone & 24.44 & 164.20 & 1.27 & $\mathrm{C}_{10} \mathrm{H}_{12} \mathrm{O}_{2}$ \\
\hline 7 & 4-(1-Hydroxyallyl)-2-methoxyphenol & 24.91 & 180.20 & 0.86 & $\mathrm{C}_{10} \mathrm{H}_{12} \mathrm{O}_{3}$ \\
\hline 8 & Zingerone & 26.56 & 194.23 & 32.07 & $\mathrm{C}_{11} \mathrm{H}_{14} \mathrm{O}_{3}$ \\
\hline 9 & $\begin{array}{l}\text { (3S,6R)-3-Hydroperoxy-3-methyl-6-(prop- } \\
\text { 1-en-2-yl)cyclohex-1-ene }\end{array}$ & 26.93 & 168.23 & 0.82 & $\mathrm{C}_{10} \mathrm{H}_{16} \mathrm{O}_{2}$ \\
\hline 10 & Nonane, 1,9-dibromo & 27.57 & 286.05 & 0.6 & $\mathrm{C}_{9} \mathrm{H}_{18} \mathrm{Br}_{2}$ \\
\hline 11 & $\begin{array}{l}\text { 1,3-Benzenediol, 4-[2,2,2-trifluoro-1- } \\
\text { hydroxy-1-(trifluoromethyl)ethyl] }\end{array}$ & 38.10 & 276.13 & 0.91 & $\mathrm{C}_{9} \mathrm{H}_{6} \mathrm{~F}_{6} \mathrm{O}_{3}$ \\
\hline 12 & (6)-Shogaol & 39.01 & 276.37 & 21.98 & $\mathrm{C}_{17} \mathrm{H}_{24} \mathrm{O}_{3}$ \\
\hline 13 & $\begin{array}{l}\text { Hexanoic acid, 2,7-dimethyloct-7-en-5-yn- } \\
4 \text {-yl ester }\end{array}$ & 40.47 & 250.38 & 0.81 & $\mathrm{C}_{16} \mathrm{H}_{26} \mathrm{O}_{2}$ \\
\hline 14 & $\beta$-Dihydroagarofuran & 41.23 & 222.37 & 8.5 & $\mathrm{C}_{15} \mathrm{H}_{26} \mathrm{O}$ \\
\hline 15 & Phthalic acid, di(2-propylpentyl) ester & 41.46 & 390.56 & 95.29 & $\mathrm{C}_{24} \mathrm{H}_{38} \mathrm{O}_{4}$ \\
\hline
\end{tabular}


Aji N, et al.: Antibacterial Activity and Active Fraction of Zingiber officinale Roscoe, Zingiber montanum (J.Koenig) Link ex A., and Zingiber zerumbet (L.) Roscoe ex Sm. Against Propionibacterium acnes

Table 6: Phytochemical components identified in the Z. montanum ethyl acetate fraction by GC-MS.

\begin{tabular}{|c|c|c|c|c|c|}
\hline No. & Name of the compound & Retention Time & $\begin{array}{l}\text { Molecular weight } \\
(\mathrm{g} / \mathrm{mol})\end{array}$ & $\begin{array}{l}\text { Peak Area } \\
\text { (\%) }\end{array}$ & Formula \\
\hline 1 & Terpinen-4-ol & 14.66 & 154.25 & 3.44 & $\mathrm{C}_{10} \mathrm{H}_{18} \mathrm{O}$ \\
\hline 2 & Isovanillin & 20.61 & 152.15 & 1.36 & $\mathrm{C}_{8} \mathrm{H}_{8} \mathrm{O}_{3}$ \\
\hline 3 & Menthane, 1,2,4-trihydroxy & 23.02 & 188.26 & 1.73 & $\mathrm{C}_{10} \mathrm{H}_{20} \mathrm{O}_{3}$ \\
\hline 4 & Methylisoeugenol & 25.37 & 178.23 & 1.79 & $\mathrm{C}_{11} \mathrm{H}_{14} \mathrm{O}_{2}$ \\
\hline 5 & Benzene, 4-(1E)-1,3-butadien-1-yl-1,2-dimethoxy & 26.27 & 190.24 & 38.04 & $\mathrm{C}_{12} \mathrm{H}_{14} \mathrm{O}_{2}$ \\
\hline 6 & $\begin{array}{l}\text { (Z)-1-(Buta-1,3-dien-1-yl)-2,4,5- } \\
\text { trimethoxybenzene }\end{array}$ & 30.22 & 220.26 & 6.74 & $\mathrm{C}_{13} \mathrm{H}_{16} \mathrm{O}_{3}$ \\
\hline 7 & (E)-4-(3,4-Dimethoxyphenyl)but-3-en-1-ol & 31.42 & 208.25 & 99.68 & $\mathrm{C}_{12} \mathrm{H}_{16} \mathrm{O}_{3}$ \\
\hline 8 & $\begin{array}{l}\text { 1-(3,4-Dimethoxyphenyl)-2-(N-hydroxyamino) } \\
\text { propan-1-ol }\end{array}$ & 32.24 & 177.24 & 1.32 & $\mathrm{C}_{11} \mathrm{H}_{15} \mathrm{NO}$ \\
\hline 9 & (E)-4-(3,4-Dimethoxyphenyl)but-3-en-1-yl acetate & 34.08 & 250.29 & 22.82 & $\mathrm{C}_{14} \mathrm{H}_{18} \mathrm{O}_{4}$ \\
\hline 10 & Hexanedioic acid, dioctyl ester & 40.07 & 370.57 & 1.7 & $\mathrm{C}_{22} \mathrm{H}_{42} \mathrm{O}_{4}$ \\
\hline 11 & 1,2-Benzenedicarboxylic acid, bis(2-ethylhexyl) ester & 41.45 & 390.56 & 11.07 & $\mathrm{C}_{24} \mathrm{H}_{38} \mathrm{O}_{4}$ \\
\hline 12 & $\begin{array}{l}\text { trans-3-(3,4-Dimethoxyphenyl)-4-[(E)-3',4'- } \\
\text { dimethoxystyryl]cyclohex-1-ene }\end{array}$ & 45.46 & 380.48 & 17.56 & $\mathrm{C}_{24} \mathrm{H}_{28} \mathrm{O}_{4}$ \\
\hline
\end{tabular}

Table 7: TLC results of ethyl acetate fraction.

\begin{tabular}{ccccc}
\hline No. $\mathbf{R f}$ & Z. officinale & Z. montanum & Quercetin & 0.91 \\
1 & 0.14 & 0.14 & - & - \\
2 & 0.29 & 0.27 & - & - \\
3 & 0.43 & 0.30 & - & - \\
4 & 0.55 & 0.53 & - & - \\
5 & 0.71 & $0.57^{*}$ & - & - \\
6 & 0.83 & 0.73 & 0.94 & -
\end{tabular}

Note : ${ }^{*} \mathrm{Rf}$ is equal to standard.

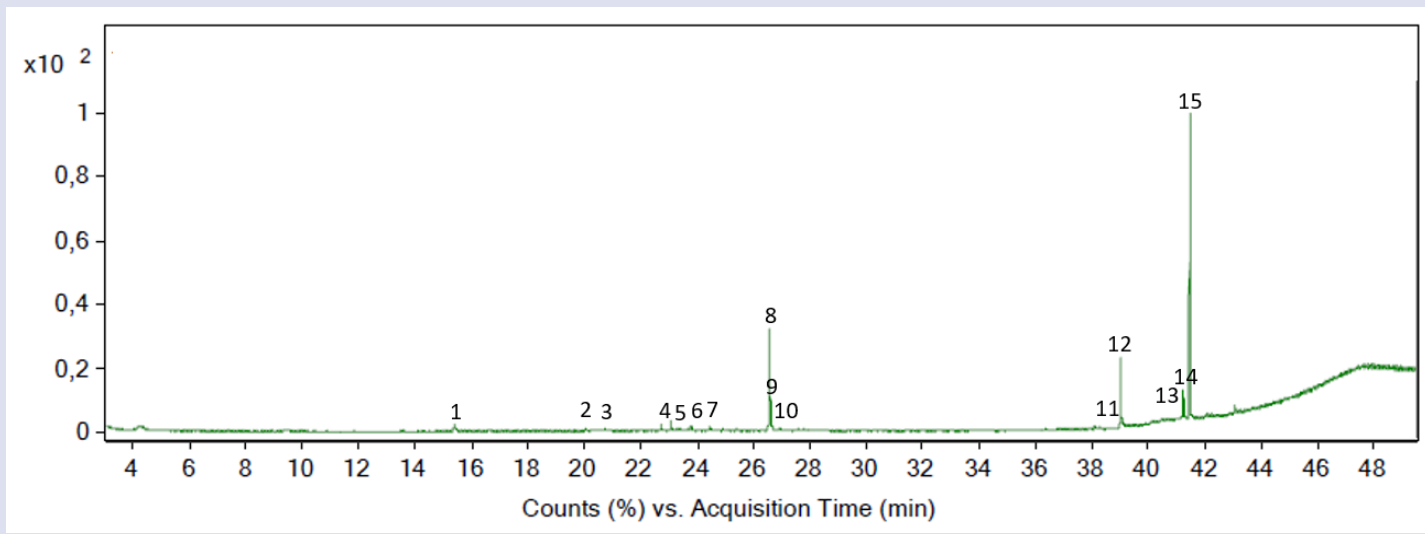

Figure 6: GC-MS chromatogram of Z. officinale ethyl acetate fraction.

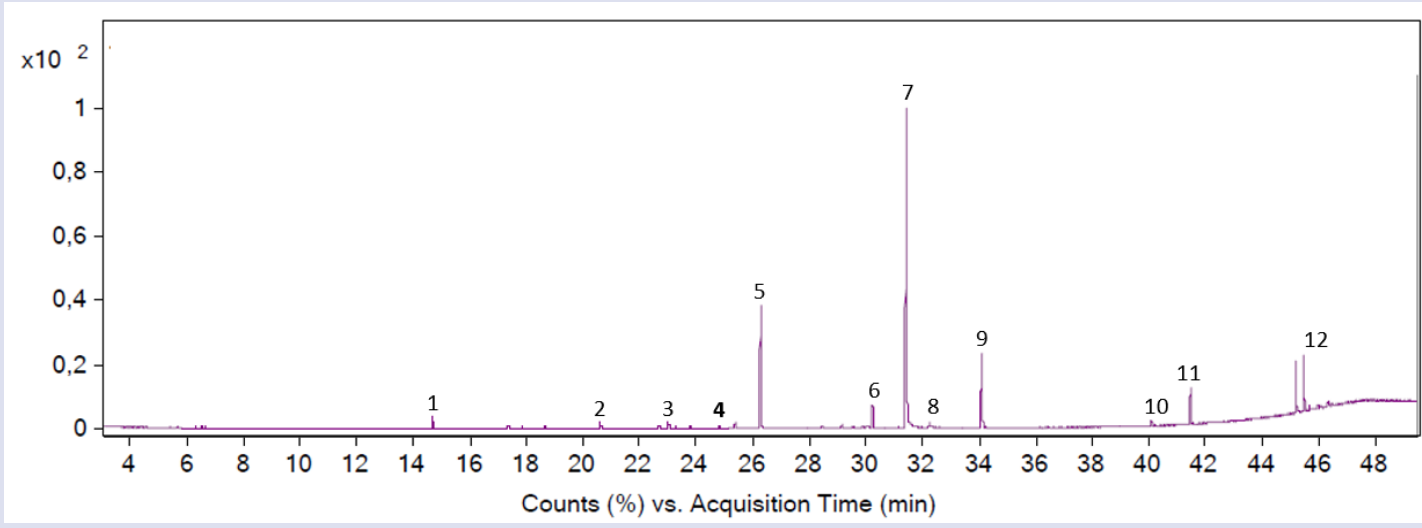

Figure 7: GC-MS chromatogram of Z. montanum ethyl acetate fraction. 


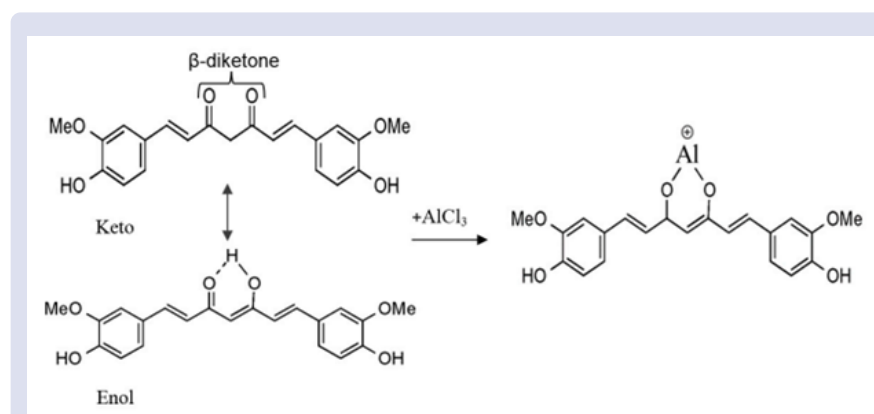

Figure 8: Transformation dike to enol group fungs ion and complex with aluminium ion ${ }^{20}$.

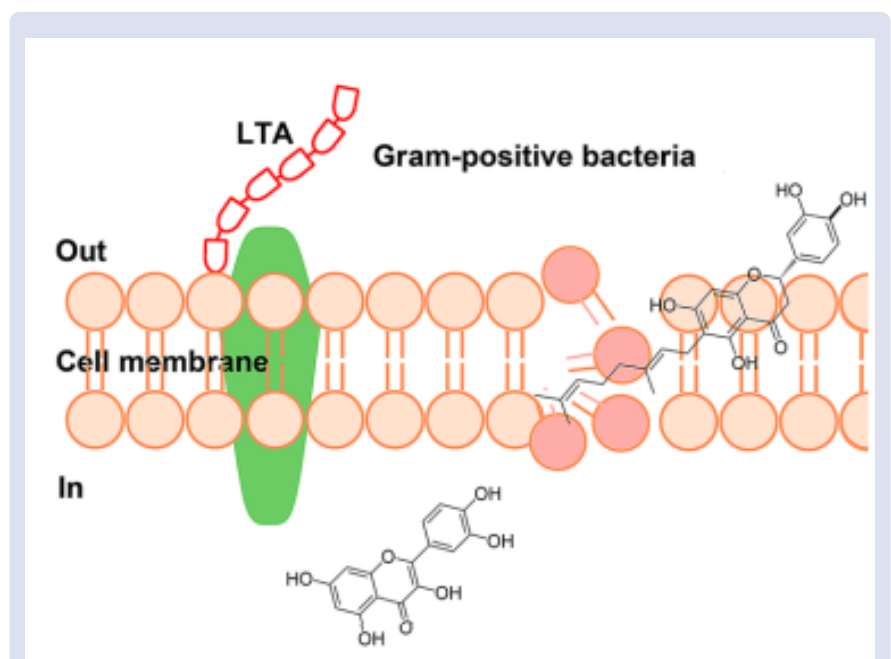

Figure 9: Diagrammatic mechanisms of plant favonoids to cell membrane bacteria $^{22}$

The antibacterial activity of the three extracts can be seen in Figure 4. The results of the analyses of variant the antibacterial activity of the three species were significantly different (Sig. $<0.05$ ). The highest activity was in $Z$. officinale extract, followed by $Z$. montanum and the smallest was $Z$. zerumbet. Based on the antibacterial activity test, the extracts of $Z$. officinale and $Z$. montanum extracts were continued for fractionation. The results of the fractionation and antibacterial activity test showed two fractions had a high inhibition zone, the active fractions are ethyl acetate $Z$. officinale and ethyl acetate $Z$. montanum (Figure 5). Comparison of the antibacterial test results of the extract with the ethyl acetate fraction experienced a significant increase in the inhibition zone for Z. montanum (Sig. < 0.05) while $Z$. officinale an increase in the inhibition zone but not significant (Sig. $>0.05$ ). The increase in antibacterial activity was due to the phytochemical compounds being less, so that in the fraction which allowed the interaction between the antagonist active substances to be reduced.

The active ethyl acetate fractions of $Z$. officinale and Z. montanum were screened using GC-MS and obtained 15 components of chemical compounds from the ethyl acetate fraction $Z$. officinale (Table 5) and 12 components from the ethyl acetate fraction $Z$. montanum (Table 6). In addition, curcumin is a compound found in the ethyl acetate fraction through thin layer chromatography (TLC) identification, curcumin was identified in the 5th spot with an Rf value of 0.57 (Table 7).

\section{DISCUSSION}

Extraction using $70 \%$ ethanol yield is shown in Table 1 . The yield was highly dependent on the water content and ethanol residue. The water content and ethanol residue in the extracts of $Z$. officinale, and $Z$. montanum had high levels compared to that of $Z$. zerumbet but still met the requirements. In addition, the yield value of the extract is influenced by the polarity of the substance that can be attracted by $70 \%$ ethanol solvent. Conformity of characteristics of solute-solvent interactions according to the classical "like dissolves like" rule. ${ }^{18}$ Ethanol $70 \%$ has a polarity index of 8.2, ethanol includes a semi-polar solvent in which polyphenolic compounds, flavonoids and some secondary metabolites as shown in Table II can be dissolved at this polarity index. ${ }^{19}$

The extract parameter of essential oils $Z$. officinale does not meet the requirements, and $Z$. zerumbet from the parameters of acidinsoluble ash content total content and essential oils. Meanwhile, $Z$. montanum from the parameter of total curcuminoid content. The minimum number of requirements based on the Indonesian Herbal Pharmacopoeia 2nd Edition standards for Z officinale essential oil is $2.40 \%$ for $Z$. officinale and $2.30 \%$ for $Z$. zerumbet. The essential oil content factor can be influenced by many factors, some of which are the process of making simplicia, the type of extract solvent and the concentration process of the extract. The extract concentration process uses a temperature of $50^{\circ} \mathrm{C}$. The components of the essential oil may contain many compounds that can evaporate under these conditions.

Testing the levels of flavonoids with UV-Vis spectrophotometric method, the principle of the reaction of flavonoids with the addition of $\mathrm{AlCl}_{3}$ will form a stable acid complex with a C-4 ketone group, as well as on the $\mathrm{C} 3$ or $\mathrm{C}-5$ hydroxyl group of flavones and flavonoids as in Figure 3. The $\mathrm{AlCl}_{3}$ also forms a stable acid complex with an orthodihydroxyl group on ring $\mathrm{A}$ or $\mathrm{B}^{17}$ (Figure 3). The high levels of flavonoids in $Z$. montanum extract, possibly due to the curcumin compound that binds $\mathrm{AlCl}_{3}$ through the diketone group which also provides absorption at a wavelength of $445 \mathrm{~nm}$ (Figure 8). ${ }^{20}$

The antibacterial activity of ginger has the greatest inhibition zone compared to the other two species ( $Z$. montanum and $Z$. zerumbet) this is due to the presence of phytochemicals in the form of flavonoid compounds (the results of phytochemical screening). The antibacterial action mechanism of flavonoids is highly dependent on the flavonoid class structure contained in ginger. Based on research by Zubair MS, et $a l^{21}$ the flavonoid contained in $Z$. officinale is 5-hydro-7,8,20trimethoxyflavanone. The flavonoid group of the flavonone class has an anti-bacterial mechanism of action by inhibiting the cytoplasmic membrane function on membrane fluidity was studied using liposomal model membranes (Figure 9). ${ }^{22}$

The ethyl acetate fraction of $Z$. officinale has antibacterial activity identified by GC-MS including phenol compounds: frambinone, 4-(1-Hydroxyallyl)-2-methoxyphenol; zingerone; 1,3-benzenediol; and 4-[2,2,2-trifluoro-1-hydroxy-1-(trifluoromethyl)ethyl]. The phenol-derived compound that has antibacterial activity by damaging bacterial cell membranes. ${ }^{23}$ The sesquiterpenes are: $\alpha$-curcumene; $\alpha$-zingiberene; trans- $\beta$-farnesene; and dihydro-beta-agarofuran. The detected oleoresin compound was 6-shogaol, both sesquiterpene and oleoresin compounds having phenol groups have the same antibacterial mechanism of action as monoterpenes. The compound, 6-Shogaol is the dominant compound in ginger resulting from dehydration of 6-gingerol, the conversion process can be triggered by heating. ${ }^{24}$

The ethyl acetate fraction also detected an unsaturated aliphatic aldehyde compound is decanal. Based on Soliman, S.S., et al ${ }^{25}$ decanal is an antibacterial agent. Decanal compounds have a mechanism of action due to aldehyde groups which are very likely to cause the function of cell membrane proteins, thereby increasing their permeability. ${ }^{26,27}$ The ester compounds such as Hexanoic acid, 2,7-dimethyloct-7-en-5-yn4 -yl ester; and phthalic acid, di(2-propylpentyl) ester is not yet known with certainty how the effect as an antibacterial and the mechanism of action. The zingerone ${ }^{28}$ and 6-shogaol ${ }^{29}$ compounds in ginger are 
known to have the activity of inhibiting the formation of biofilms on bacteria. Biofilm formation in P. acnes is one of the mechanisms of colonization and antimicrobial resistance. ${ }^{30,31}$

The second extract that had high antibacterial activity against $P$. acnes was $Z$. montanum. Compounds related to antibacterial activity in the extract are flavonoids (the result of phytochemical screening). The active fraction of $Z$. montanum, are ethyl acetate fraction, showed that the results of the GC-MS screening contained monoterpene compounds: Terpinen-4-ol, phenol compounds: isovanillin; benzene, 4-(1E)-1,3-butadiene-1-yl-1,2-dimethoxy; 1-(3,4-dimethoxyphenyl)2-(n-hydroxyamino)propan-1-ol; Cyclic polyalcoholic compounds: menthane, 1,2,4-trihydroxy, phenol esters: methylisoeugenol; (E)-4(3,4-dimethoxyphenyl)but-3-en-1-ol; (E)-4-(3,4-dimethoxyphenyl) but-3-en-1-yl acetate. Others : (Z)-1-(Blind-1,3-dien-1-yl)-2,4,5trimethoxybenzene; 1-(3,4-dimethoxyphenyl)-2-(n-hydroxyamino) propan-1-ol; hexanedioic acid, dioctyl ester; 1,2-benzenedicarboxylic acid, bis(2-ethylhexyl) ester; trans-3-(3,4-Dimethoxyphenyl)-4-[(E)3',4'-dimethoxystyryl]cyclohex-1-ene. Same as in Z. officinale phenolic compounds, monoterpenes and sesquiterpenes have mechanisms against bacterial cell membranes. ${ }^{32}$

Terpinen-4-ol is the main component of $Z$. montanum rhizomes. This compound has antibacterial activity and can also inhibit the formation of biofilms from bacteria. ${ }^{33,34}$ The results of thin layer chromatography in the ethyl acetate fraction contain a non-volatile compound is curcumin. The mechanism of curcumin is blocks bacterial growth, that inhibit bacterial virulence factors, inhibit bacterial biofilm formation and prevent bacterial adhesion to host receptors through the bacterial quorum sensing regulation system. ${ }^{35}$

\section{CONCLUSION}

The $70 \%$ ethanol extract of $Z$. officinale, $Z$. montanum and $Z$. zerumbet had antibacterial activity against $P$. acnes. The highest activity was on $Z$. officinale both extract and active fraction. The active fraction ethyl acetate is the fraction with the highest inhibition zone, containing compounds consisting of 15 components including monoterpenoidssesquiterpenes and oleoresin (6-shogaol) groups.

\section{REFERENCES}

1. Platsidaki E, Dessinioti C. Recent advances in understanding Propionibacterium acnes (Cutibacterium acnes) in acne. F1000Research. 2018;7.

2. Dréno B, Pécastaings $S$, Corvec $S$, Veraldi $S$, Khammari A, Roques C. Cutibacterium acnes (Propionibacterium acnes) and acne vulgaris: a brief look at the latest updates. J Eur Acad Dermatology Venereol. 2018;32:5-14

3. Achermann Y, Goldstein EJC, Coenye T, Shirtliff ME. Propionibacterium acnes: from commensal to opportunistic biofilmassociated implant pathogen. Clin Microbiol Rev. 2014;27(3):41940.

4. Syafitri DM, Levita J, Mutakin M, Diantini A. A Review: Is Ginger (Zingiber officinale var. Roscoe ) Potential for Future Phytomedicine? Indones J Agric Sci. 2018;8(4):1-6.

5. Setiyono A. Indonesian wild ginger (Zingiber sp.) extract: Antibacterial activity against mycoplasma gallisepticum. IOSR J Pharm. 2015;5:59-64.

6. Koch W, Kukula-koch W, Marzec Z, Kasperek E. Application of Chromatographic and Spectroscopic Methods towards the Quality Assessment of Ginger ( Zingiber officinale) Rhizomes from Ecological Plantations. Int J Mol Sci. 2017;18(452):1-15.

7. Nagano T, Oyama Y, Kajita N, Chikahisa L, Nakata M, Okazaki E, et al. New curcuminoids isolated from Zingiber cassumunar protect cells suffering from oxidative stress: a flow-cytometric study using rat thymocytes and H202. Jpn J Pharmacol. 1997;75(4):363-70.
8. Kel'in A V. Recent advances in the synthesis of 1, 3-diketones. Curr Org Chem. 2003;7(16):1691-711

9. Koga AY, Beltrame FL, Pereira A V. Several aspects of Zingiber zerumbet: a review. Rev Bras Farmacogn. 2016;26(3):385-91.

10. DepKes RI. Indonesian Herbal Pharmacopoeia 1st Edition. 1st ed. Ministry of Health Republic of Indonesia. Jakarta; 2008.

11. Farnsworth NR. Biological and phytochemical screening of plants. J Pharm Sci. 1966;55(3):225-76.

12. Republic of Indonesia K. Indonesian Herbal Pharmacopoeia 2nd edition. 2nd ed. Jakarta: Kemenkes RI; 2017

13. DEPKES RI. Indonesian Pharmacopoeia 3rd Edition. 3rd ed. Jakarta: Ministry of Health Republic of Indonesia; 1979.

14. Masuda T, Jitoe A. Antioxidative and antiinflammatory compounds from tropical gingers: isolation, structure determination, and activities of cassumunins $A, B$, and $C$, new complex curcuminoids from Zingiber cassumunar. J Agric Food Chem. 1994;42(9):1850-6.

15. Winato BM, Sanjaya E, Siregar L, Kifami S, Maria Y, Fau V, et al. Acnes Antibacterial Activity Of Serai Wangi Leaf Extract ( Cymbopogon nardus ) Against Propionibacterium acnes. J Biol Lingkung. 2019;6(1).

16. Hu C, Liu Y. Quality control in pharmaceuticals: residual solvents testing and analysis. Wide Spectra Qual Control INTECH. 2011;183-210.

17. Makuasa DAA, Ningsih $P$. The Analysis of Total Flavonoid Levels In Young Leaves and Old Soursop Leaves (Annona muricata L.) Using UV-Vis Sepctrofotometry Methods. J Appl Sci Eng Technol Educ. 2020;2(1):11-7

18. Chew KK, Khoo MZ, Ng SY, Thoo YY, Aida WWM, Ho CW. Effect of ethanol concentration, extraction time and extraction temperature on the recovery of phenolic compounds and antioxidant capacity of Orthosiphon stamineus extracts. Int Food Res J. 2011;18(4):1427.

19. Markom M, Hasan M, Daud WRW, Singh $H$, Jahim JM. Extraction of hydrolysable tannins from Phyllanthus niruri Linn.: Effects of solvents and extraction methods. Sep Purif Technol. 2007;52(3):487-96

20. Sepahpour S, Selamat J, Abdul Manap MY, Khatib A, Abdull Razis AF. Comparative analysis of chemical composition, antioxidant activity and quantitative characterization of some phenolic compounds in selected herbs and spices in different solvent extraction systems. Molecules. 2018;23(2):402.

21. Zubair MS, Maulana S, Widodo A, Pitopang R, Arba M, Hariono M. GC-MS, LC-MS/MS, Docking and molecular dynamics approaches to identify potential SARS-CoV-2 3-chymotrypsin-like protease inhibitors from Zingiber officinale Roscoe. Molecules. $2021 ; 26(17): 5230$.

22. Cushnie TPT, Lamb AJ. Antimicrobial activity of flavonoids. Int J Antimicrob Agents. 2005;26(5):343-56.

23. Rempe CS, Burris KP, Lenaghan SC, Stewart Jr CN. The potentia of systems biology to discover antibacterial mechanisms of plant phenolics. Front Microbiol. 2017;8:422.

24. Ko M-J, Nam H-H, Chung M-S. Conversion of 6-gingerol to 6-shogaol in ginger (Zingiber officinale) pulp and peel during subcritical water extraction. Food Chem. 2019;270:149-55.

25. Soliman SSM, Saeed BO, Elseginy SA, Al-Marzooq F, Ahmady IM, El-Keblawy AA, et al. Critical discovery and synthesis of novel antibacterial and resistance-modifying agents inspired by plant phytochemical defense mechanisms. Chem Biol Interact. $2021 ; 333: 109318$

26. Boakye YD, Osafo N, Danquah CA, Adu F, Agyare C. Antimicrobial agents: Antibacterial agents, anti-biofilm agents, antibacterial natural compounds, and antibacterial chemicals. Antimicrob Antibiot Resist Antibiofilm Strateg Act Methods. 2019;75.

27. Bisignano G, Laganà MG, Trombetta $D$, Arena $S$, Nostro A, Uccella $\mathrm{N}$, et al. In vitro antibacterial activity of some aliphatic aldehydes from Olea europaea L. FEMS Microbiol Lett. 2001;198(1):9-13. 
28. Kumar L, Chhibber S, Harjai K. Zingerone inhibit biofilm formation and improve antibiofilm efficacy of ciprofloxacin against Pseudomonas aeruginosa PAO1. Fitoterapia. 2013;90:73-8.

29. Kim H, Eom Y. Antifungal and anti-biofilm effects of 6-shogaol against Candida auris. J Appl Microbiol. 2021;130(4):1142-53.

30. Beylot C, Auffret N, Poli F, Claudel J, Leccia M, Del Giudice P, et al. Propionibacterium acnes: an update on its role in the pathogenesis of acne. J Eur Acad Dermatology Venereol. 2014;28(3):271-8.

31. Lambrechts IA, de Canha MN, Lall N. Exploiting medicinal plants as possible treatments for acne vulgaris. In: Medicinal Plants for Holistic Health and Well-Being. Elsevier; 2018;117-43.
32. Trombetta D, Castelli F, Sarpietro MG, Venuti V, Cristani M, Daniele $C$, et al. Mechanisms of antibacterial action of three monoterpenes. Antimicrob Agents Chemother. 2005;49(6):2474-8.

33. Zhang Y, Feng R, Li L, Zhou X, Li Z, Jia R, et al. The antibacterial mechanism of terpinen-4-ol against Streptococcus agalactiae. Curr Microbiol. 2018;75(9):1214-20.

34. Khaw-On P, Banjerdpongchai R. Induction of intrinsic and extrinsic apoptosis pathways in the human leukemic MOLT-4 cell line by terpinen-4-ol. Asian Pacific J Cancer Prev. 2012;13(7):3073-6.

35. Zheng $D$, Huang $C$, Huang $H$, Zhao $Y$, Khan MRU, Zhao $H$, et al Antibacterial mechanism of curcumin: A review. Chem Biodivers. 2020:17(8):e2000171.

\section{GRAPHICAL ABSTRACT}
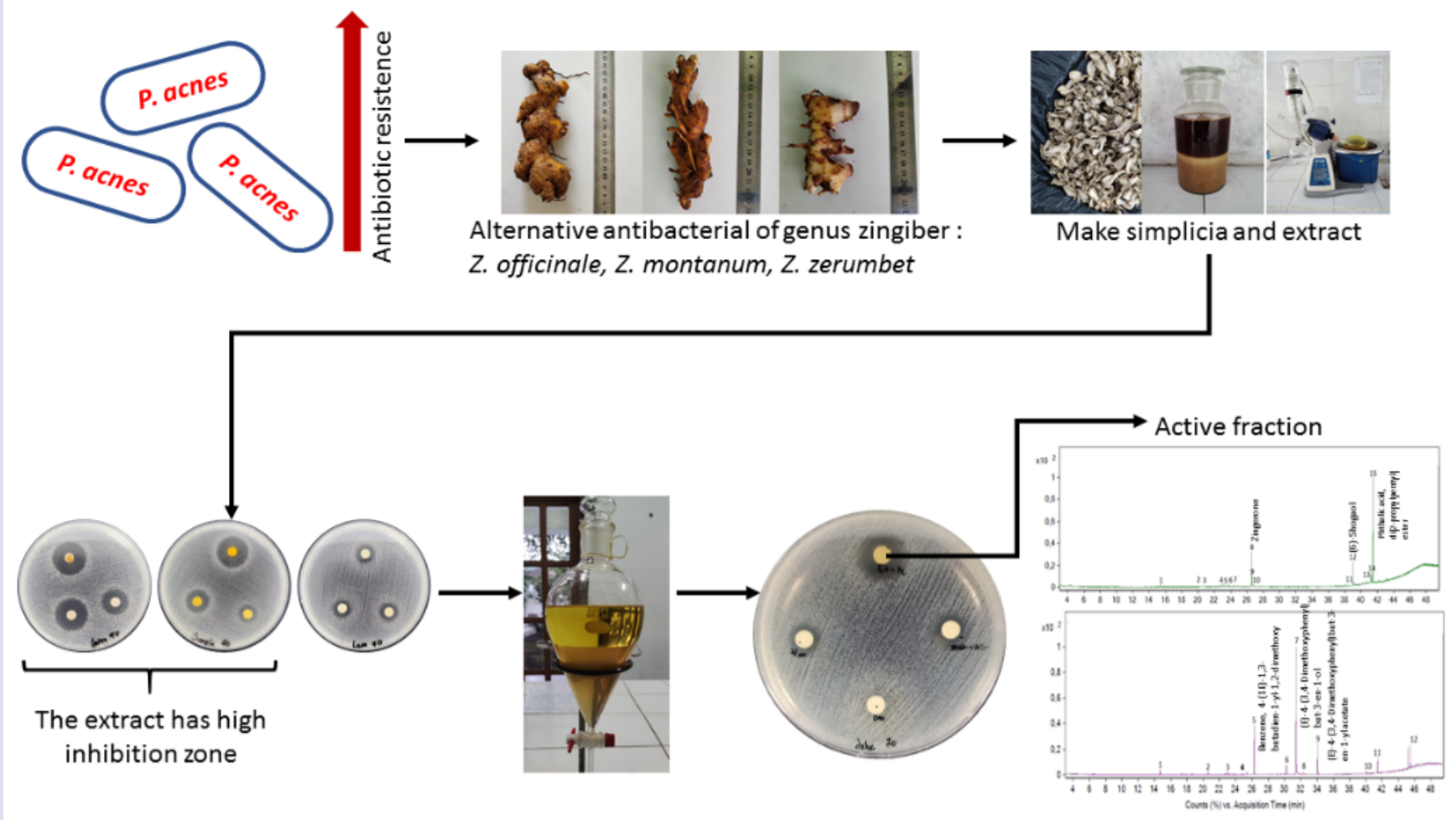


\section{ABOUT AUTHORS}

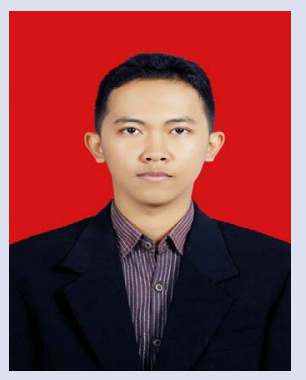

Nur Aji is a master's degree graduate in the pharmacy study program at Pancasila University in 2017. He is a lecturer at the Department of Pharmacy, Health Polytechnic Ministry of Health Tasikmalaya. The deepening of research on natural pharmaceutical drugs and cosmetic technology based on natural ingredients.

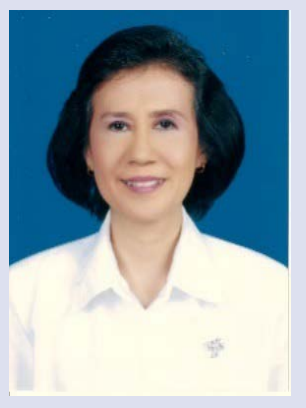

Shirly Kumala has completed her PhD from Biomedical Faculty, University of Indonesia, Jakarta. She is the Dean of Pharmacy Faculty, Universitas Pancasila, Jakarta, Indonesia. Her area of research is Microbioloy, focussing on endophytic microbes, antimicrobial and antibiotic resistance of herbal plant extracts. She has published more papers both International and National Journals and has been serving as a reviewer in Journal of Pharmacy.

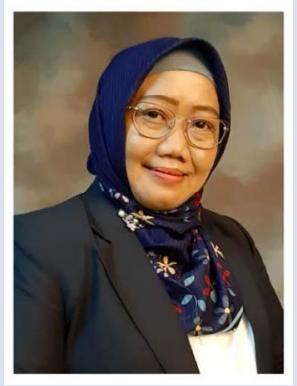

Esti Mumpuni is a lecturer at the Faculty of Pharmacy, Pancasila University. She completed her last education in the Doctoral program at the Faculty of Pharmacy UGM in 2016. Her research focus includes medicinal chemistry, organic chemistry, bioinformatic and the synthesis of medicinal compounds. She Currently she is active in many courses such as Organic Chemistry, Bioinformatic, biotechnology and Technology of separation.

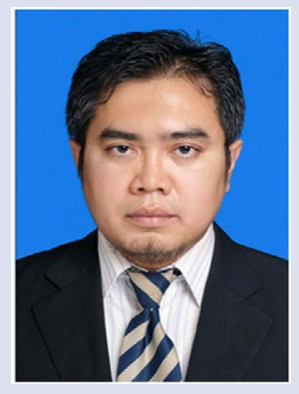

Deni Rahmat obtained his PhD in 2012 from Innsbruck University, Austria. He is currently a lecturer in the department of pharmaceutical technology, Universitas Pancasila, Jakarta, Indonesia and the chairman of International Conference of Pharmaceutical Nanotechnology/ Nanomedicine Indonesia. He has contributed in the field of pharmaceutical nanotechnology in Indonesia and authored a lot of publications.

Cite this article: Aji N, Kumala S, Mumpuni E, Rahmat D. Antibacterial Activity and Active Fraction of Zingiber officinale Roscoe, Zingiber montanum (J.Koenig) Link ex A., and Zingiber zerumbet (L.) Roscoe ex Sm. Against Propionibacterium acnes. Pharmacogn J. 2022;14(1): 103-111. 